Faktor Risiko Yang Mempengaruhi Terjadinya Kejadian Demam Berdarah Dengue (DBD) Di Puskesmas Sewon II Bantul

(Risk Factors Affecting The Incidence Of Dengue Hemorrhagic Fever (DHF) In Puskesmas Sewon II Bantul)

\title{
Ubaidillah$^{1 *}$, Deden Kurniawan¹,
}

${ }^{1}$ Kesehatan Masyarakat Stikes Surya Global Yogyakarta

*Koresponden Penulis: bd_ubaidillah@yahoo.com

\begin{abstract}
ABSTRAK
Berdasarkan data Dinas Kesehatan Kabutapten Bantul, data demam Berdarah Dengue dari seluruh Puskesmas di kabupaten Bantul Tahun 2017 menunjukan Puskesmas Sewon II menempati urutan pertama kejadian DBD dengan kasus sebanyak 44 kasus dan berdasarkan Data Puskesmas Sewon kabupaten Bantul terdapat 40 kasus kejadian Demam Berdarah. Tujuan penelitian ini untuk mengetahui Faktor-Faktor Risiko Yang Mempengaruhi Terjadinya Penyakit Demam Berdarah Dengue (DBD) di wilayah kerja Puskesmas Sewon II Bantul Tahun 2018. Metode penelitian menggunakan desain penelitian kuantitatif dengan rancangan penelitian case control. Jumlah sampel dalam penelitian ini sebanyak 40 kasus dan 40 kontrol, menggunkan teknik purposive sampling. Penelitian dilaksanakan pada bulan april 2018 dengan wawancara menggunkan kuesioner. Analisis data menggunakan uji chi-square dengan program SPSS. Hasil penelitian menunjukkan terdapat hubungan yang bermakna antara membersihkan tempat penampungan air, tidak mengubur barang-barang bekas, Tidak menabur bubuk abate dengan kejadian Demam Berdarah Dengue pada pasien di Wilayah Kerja Puskesmas Sewon II Bantul. Tidak terdapat hubungan yang bermakna antara menggantung pakaian dengan kejadian Demam Berdarah Dengue pada pasien di Wilayah Kerja Puskesmas Sewon II Bantul.
\end{abstract}

Kata kunci: Demam Berdarah Dengue (DBD), mengubur barang bekas, menggantung pakaian, abate.

\begin{abstract}
Based on data from Bantul District Health Office, dengue fever data from all Puskesmas in Bantul regency in 2017 shows Puskesmas Sewon II ranks first case of DHF with case as many as 44 cases and based on data of Puskesmas Sewon Bantul regency there are 40 case of Dengue fever. This studi aims to determine the risk factors that influence the occurrence of Dengue Hemorrhagic Fever (DHF) in the work area of Sewon II Bantul Public Health Center in 2018. The research method used quantitative research design with case control research design. The number of samples in this study were 40 cases and 40 controls, using purposive sampling technique. The study was conducted in April 2018 by interview using a questionnaire. Data analysis using chi-square test with SPSS program. The result shows that there is a significant relationship between cleaning up water reservoirs, not burying used goods, not sowing abate powder with the occurrence of Dengue Hemorrhagic Fever in patients in Public Health Center the Sewon II Bantul. There is no significant relationship between hanging clothes with the occurrence of Dengue Hemorrhagic Fever in patients Public Health Center in the Sewon II Bantul
\end{abstract}

Keywords: Dengue Haemorrhagic Fever, buried secondhand goods, hanging clothes, Abate. 
8 | Jurnal Kesmas Untika Luwuk: Public Health Journal, 11 (1) : 7-12

\section{PENDAHULUAN}

Demam Berdarah Dengue (DBD) adalah penyakit yang disebabkan oleh virus dengue yang tergolong Arthropod-Borne Virus, genus Flavivirus, dan family flaviviridae. DBD ditularkan melalui gigitan nyamuk dari genus aedes, terutama Aedes aegypti. Penyakit DBD dapat muncul sepanjang tahun dan dapat menyerang seluruh kelompok umur. Munculnya penyakit ini berkaitan dengan kondisi lingkungan, perubahan iklim dan perilaku masyarakat (Depkes RI, 2016)(Yusnita Lalusu, Herawati, \& Kodim, 2018).

Terjadinya KLB DBD di Indonesia berhubungan dengan berbagai faktor resiko, yaitu: lingkungan yang masih kodusif untuk terjadinya tempat perindukan nyamuk Aedes; pemahaman masyarakat yang masih terbatas mengenai pentingnya pemberantasan sarang nyamuk (PSN) 3M plus; Perluasan daerah endemik akibat perubahan dan manipulasi lingkungan yang terjadi karena urbanisasi dan pembangunan tempat pemukiman baru; serta 4) Meningkatkan mobilitas penduduk (Sucipto, Raharjo, \& Nurjazuli, 2016)(Sinaga \& Hartono, 2019).

Menurut data dinas kesehatan tahun 2014 DIY jumlah kasus demam berdarah Dengue (DBD) di kota yogyakarta terus melonjak, bahkan saat ini telah menempati urutan ke 3 kasus DBD terbanyak pada awal 2016, kepala bidang Pencegahan Penyakit dan Masalah Kesehatan (P2MK) Dinas Kesehatan DIY mengungkapkan bahwa jumlah kasus DBD tertinggi berada di kabupaten bantul dengan jumlah 188 kasus.

Berdasarkan data Dinas Kesehatan Kabutapten Bantul, data demam Berdarah Dengue dari seluruh Puskesmas di kabupaten Bantul Tahun 2017 menunjukan Puskesmas Sewon II menempati urutan pertama kejadian DBD dengan kasus sebanyak 44 kasus. Kemudian urutan kedua yaitu Puskesmas Kasihan II dengan kasus sebanyak 43 kasus.

\section{METODE PENELITIAN}

Jenis penelitian ini survey analitik dengan menggunakan rancangan case control. Sampel untuk penelitian ini sebanyak 80 responden dengan 40 responden kasus dan 40 responden kontrol. Metode analisis data menggunakan analisis univariat dan bivariat dengan uji chi square.

Populasi dalam penelitian ini adalah penderita DBD di wilayah kerja Puskesmas Sewon II sebanyak 40 orang dan Populasi kontrol pada penelitian ini adalah pengunjung puskesmas Sewon II, pada Bulan Januari-Juni tahun 2017 sebanyak 40 orang. Sampel yang diambil menggunakan tehnik Purpossive sampling dimana sampel diambil berdasarkan atas kriteria yang ditetapkan oleh peneliti (Notoatmodjo, 2018).

Alat ukur yang dipergunakan dalam penelitian ini adalah kuesioner tentang faktor-faktor yang mempengaruhi terjadinya penyakit DBD. Kuesioner yang diberikan bersifat tertutup yaitu berisikan daftar pertanyaan dan responden memberikan tanda centang $(\sqrt{ })$ pada salah satu jawaban yang dianggap paling sesuai. Responden memberikan jawaban sesuai dengan yang dirasakan dan dialami

\section{HASIL}

Berdasarkan hasil penelitian yang telah dilakukan dari bulan April sampai bulan Juni 2018 di wilayah kerja Puskesmas Sewon II Bantul Yogyakarta. Dengan jumlah responden 80 orang dibagi 2 kelompok yaitu 40 responden dan 40 kasus. Responden 
Faktor Risiko yang ... (Ubaidillah \& Kurniawan) $\mid 9$

dalam penelitian ini di kategorikan dalam beberapa karakteristik yaitu jenis kelamin, umur, pendidikan dan pekerjaan. Secara lengkapnya dapat dilihat pada tabel berikut:

Tabel 1. Distribusi Frekuensi Karakteristik Responden Berdasakan Jenis Kelamin, Umur, pendidikan dan Pekerjaan Responden Di Puskesmas Sewon II Bantul Yogyakarta

\begin{tabular}{lcccc}
\hline \multicolumn{1}{c}{ Variabel Penelitian } & \multicolumn{2}{c}{ Kasus } & \multicolumn{2}{c}{ Kontrol } \\
\hline Jenis Kelamin & N & (\%) & n & (\%) \\
$\quad$ Laki-laki & & & & \\
Perempuan & 21 & 52.5 & 28 & 70 \\
Umur & 19 & 47.5 & 12 & 30 \\
$\quad<20$ tahun & & & & \\
20-25 tahun & 36 & 90 & 20 & 50 \\
$\quad>25$ tahun & 2 & 5 & 12 & 30 \\
Pendidikan & 2 & 5 & 8 & 20 \\
TK & & & & \\
PAUD & 1 & 2,5 & - & - \\
SD & 2 & 5 & - & - \\
SMP & 22 & 55 & - & - \\
SLTA/SMA/SMK & 3 & 7,5 & 8 & 20 \\
D3 & 12 & 30 & 28 & 70 \\
S1 & - & - & 1 & 2,5 \\
Pekerjaan & - & - & 3 & 7,5 \\
Pelajar/Mahasiswa & & & & \\
Guru & 39 & 97,5 & 21 & 52,5 \\
IRT & - & - & 2 & 5 \\
Wiraswasta & - & - & 1 & 2,5 \\
\end{tabular}

Variabel yang diteliti ada 4 yaitu : Pembersihan tempat penampungan air, Penguburan barang bekas, Menggantung pakaian, dan Penaburan bubuk ABATE. Dari wawancara dengan responden didapatkan hasil sbb:

Tabel 2. Distribusi frekwensi Variabel Pembersihan Tempat Penampungan Air, Mengubur barang bekas, Menggantung Pakaian dan menabur bubuk abate

\begin{tabular}{lcccc}
\multicolumn{1}{c}{ Variabel Penelitian } & \multicolumn{2}{c}{ Kasus } & \multicolumn{2}{c}{ Kontrol } \\
\cline { 2 - 5 } & n & (\%) & n & (\%) \\
\hline Pembersihan Tempat Penampungan air & 27 & 67,5 & 12 & 30 \\
Tidak Membersihkan & 13 & 32,5 & 28 & 70 \\
Membersihkan & & & & \\
Penguburan barang bekas & 23 & 57,5 & 12 & 30 \\
Tidak Mengubur & 17 & 42,5 & 28 & 70 \\
Mengubur & & & & \\
Menggantung Pakaian & 20 & 50 & 21 & 52,5 \\
Menggantung & 20 & 50 & 19 & 47,5 \\
Tidak menggantung & & & & \\
Penaburan bubuk abate & 28 & 70 & 16 & 40 \\
Tidak Menabur & 12 & 30 & 24 & 60 \\
Menabur & & & & \\
\hline
\end{tabular}


10 | Jurnal Kesmas Untika Luwuk: Public Health Journal, 11 (1) : 7-12

Dari tabel 2 dilakukan analisis bivariat sehingga di dapatkan hasil sbb :

Tabel 3. Hasil Analisis Chi-Square Variabel Membersihkan Tempat Penampungan
Air, Penguburan barang bekas, Menggantung pakaian dan Penaburan ABATE
\begin{tabular}{|lcccc} 
Jenis Variabel & Jumlah & P Value & OR & $\mathbf{9 5 \%}$ CI \\
\hline Membersihkan Tempat penampungan air & 80 & 0,002 & 4,846 & $1,882-12,482$ \\
Penguburan barang bekas & 80 & 0,024 & 3,157 & $1,255-7,938$ \\
Menggantung Pakaian & 80 & 1,000 & 0,905 & $0,376-2,175$ \\
Penaburan ABATE & 80 & 0,013 & 3,500 & $1,386-8,835$ \\
\hline
\end{tabular}

\section{PEMBAHASAN}

Tabel 1. menunjukkan hasil analisis univariat dari 40 responden kasus dan kontrol. Hasil Analisis Bivariate pada variabel tidak membersihkan tempat penampungan air dengan menggunakan uji Chi Square pada tabel 3. Menunjukkan bahwa nilai chi square yang dihasilkan yaitu $P$-value $=0.002$. Dengan hasil yang di peroleh ini menunjukan bahwa nilai sig < nilai $\alpha(p<0,05)$, sehingga dapat dinyatakan bahwa ada pengaruh siginifikan antara membersihkan tempat penampungan air dengan kejadian penyakit DBD di Wilayah Kerja Puskesmas Sewon II Bantul dan hasil dari analisis ODDS Ratio diperoleh $=4,846$ pada CI 95\% antara 1,882 sampai 12,482 yang artinya responden yang tidak membersihkan tempat penampungan air beresiko 4,846 kali lebih besar daripada sampel yang membersihkan tempat penampungan air. Hal ini sejalan dengan penelitian Cahyati dan Sanjani tahun 2017, menyatakan bahwa ada hubungan antara membersihkan tempat penampungan air dengan kejadian DBD. Hasil uji statistik diperoleh nilai $p=0,001 \quad(<0.05)$. Sehingga membersihkan tempat penampungan air mempunyai hubungan terhadap kejadian DBD di Kabupaten Semarang Tahun 2015. Tempat penampungan air yang tidak dibersihkan secara rutin akan berpotensi menjadi tempat perkembangbiakan nyamuk Aedes aegypti (Cahyati \& Sanjani, 2020).

Berdasarkan hasil analisis bivariat pada variabel tidak mengubur barang-barang bekas menunjukkan bahwa nilai chi square yang dihasilkan yaitu $P$-value $=0.024$. Dengan hasil yang di peroleh ini menunjukan bahwa nilai sig < nilai $\alpha(p<0,05)$, dapat dinyatakan bahwa ada pengaruh siginifikan antara mengubur barang-barang bekas dengan kejadian penyakit DBD di Wilayah Kerja Puskesmas Sewon II Bantul. Hasil uji statistik OR $=3,157$ pada CI 95\% antara 1,255 sampai 7,938 menunjukkan responden yang tidak mengubur barang-barang bekas beresiko 3,157 kali lebih besar daripada sampel yang mengubur barang-barang bekas. Hal ini sejalan dengan penelitian Mahardhika (2009) dan Tabanai (2017) menyatakan bahwa ada hubungan antara Mengubur Barang-barang bekas dengan kejadian DBD (Wahyu Mahardika, 2009)(Ria Rezeki Oktaviani M. Tabanal, 2017). Hasil uji statistik diperoleh nilai $p=0,0042<0.05$. Dengan demikian dapat disimpulkan bahwa Ho ditolak dan Ha diterima, sehingga mengubur barang-barang bekas mempunyai hubungan terhadap kejadian DBD di Wilayah Kerja Puskesmas Wonosari Gunung Kidul 2016, dan ini juga merupakan sikap positif masyarakat dalam rangka pencegahan penyakit Demam Berdaarah Dengue. Barang bekas seperti kaleng, botol bekas yang dibiarkan berserakan tidak dikubur bila hujan juga beresiko menjadi tempat perkembangbiakan nyamuk Aedes aegypti (Cicilia Windiyaningsih \& Tiwi Nurhastuti, 2018).

Berdasarkan hasil analisis bivariat variabel menggantung pakaian menunjukkan bahwa nilai chi square yang dihasilkan yaitu $P$-value $=1,000$. Dengan hasil yang di peroleh ini menunjukan bahwa nilai sig $>$ nilai $\alpha(p>0,05)$ dapat dinyatakan bahwa 
tidak ada pengaruh siginifikan antara menggantung pakaian dengan kejadian penyakit DBD pada pasien di Wilayah Kerja Puskesmas Sewon II Bantul. Hasil uji statistik OR $=0,905$ pada CI $95 \%$ antara 0,376 sampai 2,175

Berdasarkan hasil analisis bivariat variabel tidak menabur bubuk abate menunjukkan bahwa nilai chi square yang dihasilkan yaitu $P$-value $=0.013$. Dengan hasil yang di peroleh ini menunjukan bahwa nilai sig < nilai $\alpha(p<0,05)$, dapat dinyatakan bahwa ada pengaruh siginifikan antara menabur abate dengan kejadian penyakit DBD di Wilayah Kerja Puskesmas Sewon II Bantul. Hasil uji statistik OR = 3,500 pada CI 95\% antara 1,386 sampai 8,835 yang artinya responden yang tidak menabur abate beresiko 3,500 kali lebih besar daripada responden yang menabur abate.

Hal ini sejalan dengan penelitian Amried (2016) dan Data (2016), menyatakan bahwa ada hubungan antara menabur bubuk abate dengan kejadian DBD. Hasil uji statistik diperoleh nilai $p=0,008<0.05$. Dengan demikian dapt disimpulkan bahwa, menabur bubuk abate mempunyai hubungan terhadap kejadian DBD di kelurahan 19 November Kecamatan Wundulako Kabupaten Kolaka Tahun 2016 (Amried, Asfian, \& ainurafiq, 2016)(Pusat Data Kemenkes RI, 2016).

\section{KESIMPULAN DAN SARAN}

Terdapat hubungan yang bermakna antara membersihkan tempat penampungan air, tidak mengubur barang-barang bekas, Tidak menabur bubuk abate dengan kejadian Demam Berdarah Dengue pada pasien di Wilayah Kerja Puskesmas Sewon II Bantul. Tidak terdapat hubungan yang bermakna antara menggantung pakaian dengan kejadian Demam Berdarah Dengue pada pasien di Wilayah Kerja Puskesmas Sewon II Bantul. Perlu dilakukan kegiatan pencegahan penyakit Demam Berdarah Dengue dalam hal ini dapat berupa penyuluhan kepada masyarakat tentang pemberantasan sarang nyamuk (PSN), melakukan usaha-usaha 3 M Plus, Fogging, melakukan monitoring terhadap jalannya pemeriksaan jentik oleh kader jumantik, agar dalam pelaksanaan kegiatannya dapat dilakukan dengan maksimal serta pengendalian penyakit Demam Berdarah Dengue ini dapat diatasi.

\section{UCAPAN TERIMA KASIH}

Terima kasih kami tujukan kepada Dinas Kesehatan Kabupaten Bantul yang telah membantu dalam penyediaan data sekunder. Kepala Puskesmas Sewon II Bantul yang memberikan ijin bagi penelitian kami. Kepala Stikes surya Global yang banyak mensupport penelitian ini.

\section{DAFTAR PUSTAKA}

Amried, E., Asfian, P., \& ainurafiq, A. (2016). Faktor-faktor yang Berhubungan dengan Kejadian Demam Berdarah Dengue (Dbd) di Kelurahan 19 November Kecamatan Wundulako Kabupaten Kolaka Tahun 2016. Jurnal Ilmiah Mahasiswa Kesehatan Masyarakat Unsyiah.

Cahyati, W. H., \& Sanjani, J. S. K. (2020). Gambaran Lingkungan dan Vektor Demam Berdarah Dengue di Wilayah Kerja Puskesmas Temanggung Tahun 2017. Care: Jurnal Ilmiah Ilmu Kesehatan. https://doi.org/10.33366/jc.v8i1.1124

Cicilia Windiyaningsih, \& Tiwi Nurhastuti. (2018). Determinants of Dengue Hemorrhagic Fever Outbreak in Cipayung, East Jakarta. J. of Health Science. 
12 | Jurnal Kesmas Untika Luwuk: Public Health Journal, 11 (1) : 7-12

https://doi.org/10.17265/2328-7136/2018.02.008

Depkes RI. (2016). Kendalikan DBD Dengan PSN 3M Plus. Kementerian Kesehatan Republik Indonesia. https://doi.org/10.1109/AUSCTW.2008.4460829

Notoatmodjo. (2018). Metodologi Penelitian Kesehatan. Jakarta: Rineka Cipta. Notoatmodjo, S. (2018). Metodologi Penelitian Kesehatan. Jakarta: Rineka Cipta.

Pusat Data Kemenkes RI. (2016). “Informasi Kementerian Kesehatan. 2014." Buletin Jendela Data dan Informasi Kesehatan Penyakit Tidak Menular. Jakarta.

Ria Rezeki Oktaviani M. Tabanal. (2017). Analisis Faktor yang Mempengaruhi Kejadian Demam Berdarah Dengue (DBD) di Wilayah Endemis Landungsari Kabupaten Malang. Universuty of Muhammadiyah Malang.

Sinaga, P., \& Hartono, H. (2019). Determinan Kejadian Penyakit Demam Berdarah Dengue (DBD) di Wilayah Kerja Puskesmas Medan Johor. Jurnal Kesehatan Global. https://doi.org/10.33085/jkg.v2i3.4411

Sucipto, P. T., Raharjo, M., \& Nurjazuli, N. (2016). Faktor - Faktor Yang Mempengaruhi Kejadian Penyakit Demam Berdarah Dengue (DBD) Dan Jenis Serotipe Virus Dengue Di Kabupaten Semarang. Jurnal Kesehatan Lingkungan Indonesia. https://doi.org/10.14710/jkli.14.2.51-56

Wahyu Mahardika. (2009). Hubungan antara perilaku kesehatan dengan Kejadian demam berdarah dengue (dbd) Di wilayah kerja puskesmas cepiring Kecamatan cepiring kabupaten Kendal Tahun 2009. Universitas Negeri Semarang.

Yusnita Lalusu, E., Herawati, H., \& Kodim, N. (2018). Climate Change And Dengue Hemorrhagic Fever In Banggai Regency. https://doi.org/10.2991/phico-17.2018.10 